
\title{
$\begin{array}{ll}\text { Research Square } & \begin{array}{l}\text { Preprints are preliminary reports that have not undergone peer review. } \\ \text { They should not be considered conclusive, used to inform clinical practice, } \\ \text { or referenced by the media as validated information. }\end{array}\end{array}$
}

\section{Role of family functioning and health-related quality of life in pre- school children with dental caries. A cross-sectional study}

\author{
Sobia Bilal ( $\nabla$ sobiabilal@imu.edu.my ) \\ International Medical University https://orcid.org/0000-0003-1774-7955 \\ Anshad Mohamed Abdulla \\ King Khalid University \\ Niekla Survia Andiesta \\ School of Dentistry, International Medical University \\ Muneer Gohar Babar \\ School of Dentistry, International Medical University \\ Allan Pau Kah Heng \\ School of Dentistry, International Medical University
}

\section{Research}

Keywords: Dental caries, Health-related quality of life, pre-school children, family functioning, impact

Posted Date: February 19th, 2021

DOI: https://doi.org/10.21203/rs.3.rs-213120/v1

License: (c) (i) This work is licensed under a Creative Commons Attribution 4.0 International License. Read Full License

Version of Record: A version of this preprint was published at Health and Quality of Life Outcomes on August 3rd, 2021. See the published version at https://doi.org/10.1186/s12955-021-01828-3. 


\section{Abstract \\ Background}

The aim of this cross-sectional study was to extend the earlier researches and to evaluate the effect of family functioning on oral health related quality of life (OHRQoL) and caries status in a sample of 4-to 6-year-old Chinese pre-school children in Malaysia.

\section{Methodology:}

This study was approved by the institutional Joint Research and Ethics Committee, International Medical University, Malaysia (number 373/2016); consisted of 180 eligible pre-school children from a private school. Study tools included demographic, clinical oral health data form, the ECOHIS (Early Childhood Oral Health Impact Scale) and family functioning - 12-item general functioning subscale (GF-12). Written consent was sought prior to data collection. Data were analysed by SPSS v.22.0; descriptive statistics for socio-demographic details, clinical information, HRQoL and FAD scores. The parametric tests included independent sample t-test and ANOVA to evaluate the associations between the dependent variable. Binary logistic regression models were used to assess the impacts on OHRQoL $(P$ value $<0.05)$.

\section{Results}

A response rate of $80.5 \%$ was achieved. Sample means for FAD-GF12 items fell in the nonclinical range score $<2$, indicating normal family functioning. The ECOHIS scores mean was $0.52(S D=0.68)$. The highest score of impacts reported was 20 on the children impact section (CIS) and 12 on family impact section (FIS). It was observed that children with dental caries had a significant $(P=0.014)$ negative impact on OHRQoL (mean $0.72, S D=0.50$ ) as compared to children with no caries (mean $0.34 \mathrm{SD}=0.39$ ). The bivariate regression analysis showed that family functioning and dental caries status were associated with the outcome. The odds suggested, children with Poor family functioning were six times more likely to have poor OHRQoL as compared to those with good family functioning. After adjusting it with family functioning, the odds were decreased (3.17) suggesting that poor family functioning can lower the OHRQoL.

\section{Conclusion}

Findings of this study indicates the policy makers to consider including a potentially important variable of family functioning in caries preventive educational healthcare programmes. This would aid in assessing and improving family functioning which in turns effects the quality of life.

\section{Background}

Dental caries occurs due to complex interaction between the biological processes in the oral cavity, individuals behaviours and societal influences. ${ }^{1}$ Children in the age group of 1-5 years have a caries pattern that differs from that of adults. This pattern of dental caries was previously known under various names as "bottle caries," "nursing caries," "baby bottle tooth decay," or "night bottle mouth" due to the then perceived primary cause which was inappropriate bottle feeding. ${ }^{2}$ But current evidence suggests that even though this habit could be an important causative factor it need not be the only etiological factor causing dental caries in children of this age group. Therefore, it is now recommended to use the term "Early Childhood Caries (ECC)" when describing any form of caries in infants and preschool children. ${ }^{3}$ In a systematic review almost 90 risk factors for ECC were described, ${ }^{4}$ due to this complex aetiology of ECC, researchers are now focussing into other risk factors involved besides inappropriate feeding and oral hygiene practices. ${ }^{5,6}$ The scope that dental caries in young children poses as a public health problem warrants further investigation into the natural progression of this disease. One such factor that could mediate the development of ECC is family environment. ${ }^{7}$ Parenting practices and family interactions may also affect child health problems e.g. dental caries. Pre-school children are wholly dependent on their families for their basic needs such as food, shelter and security and ideally families should provide environments that allow for the healthy, biological, social and psychological development and maintenance of its individual members. ${ }^{8}$ The role of parents is vital in establishing specific behaviours related to childhood dental caries, including children's oral hygiene and frequency of sugar consumption. ${ }^{9}$ Family functioning, which is the manner in which family members interact with each other and fulfil their roles and responsibilities, shapes this environment that impacts their physical and emotional health. ${ }^{10}$ It is therefore an important family characteristic to consider when examining the child's caries risk. Untreated decay can cause pain, and impair the nutritional status and physical growth. ECC is a public health problem in Malaysia affecting $75 \%$ of Malaysian preschool children, most of which remains 
untreated. ${ }^{11}$ In 2012, nearly 4000 children were referred for hospital paediatric dental services because of early childhood caries in Malaysia. ${ }^{12}$

Studies have shown that dental caries present negative impact on quality of life of children and their families, including nutrition aspects, behavioural oral symptoms and educational alterations. The oral health-related quality of life (OHRQOL) is a subjective and multidisciplinary aspect which has been studied in several countries. It embraces broad issues in its concept, such as physical, family and leisure characteristics, etc. ${ }^{13-16}$ The theoretical model explained by Kramer et al. in a study done among Brazilian pre-school children, showed association of sociodemographic, oral diseases and OHRQoL (Fig. 1). ${ }^{15}$

A family is a living, evolving institution, affected by socio-economic factors as well as by the changes that shape the social environment in which it functions. Good family functioning and strong family relationships are essential for children's physical, social and emotional development and well-being. ${ }^{17}$ The importance of parenting in a family arises from its role as a buffer against adversity (such as poverty or delinquent influences) or mediator of damage (as in child abuse). There is limited research on parenting styles in Asian societies such as Malaysia. In Malaysian culture families are perceived as having a collective face. In this way, the act of an individual can impact the perception of the entire family by others and the interests of the family supersede those of the individual. Malay parents are regarded as clear authority figures and are obeyed without question. The relationship between family functioning and QOL is less well studied. Family functioning may be a modifiable risk factor; if family functioning is poor, then it is a risk factor; but if it is good, then it is a protective factor. Much is understood about its aetiology and the individual characteristics that are associated with it. ${ }^{2,4,5}$ Less well understood is the effect of the immediate family environment and the conditions in which these children live, especially in the context of diverse multi-ethnic family relationships within urban and rural settings, and rapid urbanisation. Family functioning was found out to be related with various aspects of child development including physical and mental well-being. ${ }^{12,14,18}$ Based on these previous studies a positive family environment could promote the maintenance of dentally healthy behaviours through the provision of a supportive, flexible and organized family environment and vice versa. ${ }^{7}$ Also previous studies explored the social and psychosocial factors on child oral health and found that the relationships were not always independent of socioeconomic factors. ${ }^{19-22}$ Malaysia is a country known for its multi-ethnic characteristics where Malays (the largest group within Bumiputras, the name of the indigenous population) are living alongside two other communities, ethnic Chinese and ethnic Indians, who in 2010 comprised respectively 23 and $7 \%$ of the population of 28 million. ${ }^{23}$ In this study only Chinese pre-school children where included as we believe the concept of family functioning might vary in different ethnic population and in future we would like to explore this concept in the remaining two ethnic groups.

\section{Materials And Methods}

The aim of this cross-sectional study is to extend these earlier researches and to evaluate the effect of family functioning on oral health related quality of life (OHRQoL) and caries status in a sample of 4-to 6 year-old Chinese pre-school children in Malaysia. The objectives were

(i) To investigate the association between family functioning and dental caries experience, (ii) to explore whether family functioning could mediate the relationship between sociodemographic factors, childhood dental caries and OHRQoL (iii) to assess the impact of dental caries on the HRQOL of the preschool children and their families. This cross-sectional study was approved by the institutional Joint Research and Ethics Committee (number 373/2016). The sample consisted of 180 eligible pre-school children from a private school in Malaysia. This school is an international setting with pre-school, primary and secondary sections. The children studying in this school learn Mandarin as their first language. The study sample included 4-6 years old Chinese pre-school children. There were 7 classes with around $25-26$ students in each class. All the students were included in the study regardless of the gender. Children who had reached the age of six, but have not had their seventh birthday on the date of examination were included in the study.

\section{Data collection}

\section{Measures:}

The selected questionnaires were translated into Mandarin to address the language barrier. The following forms and questionnaires were used for data collection:

1. Demographic questionnaire: A demographic questionnaire assessing the family characteristics (e.g., number of siblings, household income, parental education, employment status) was completed by parents.

2. Clinical Oral Health data form: Clinical oral health data were collected through this form. The number of decayed, missing (due to caries) and filled deciduous teeth (dmft) were recorded. The diagnosis of caries was based on the dmft index, ${ }^{24}$ which allows professionals to measure and to compare the dental caries experience in populations. 
1. Oral health-related quality of life (OHRQOL) assessed using the ECOHIS (Early Childhood Oral Health Impact Scale): The Early Childhood Oral Health Impact Scale (ECOHIS), initially proposed by Pahel et al. ${ }^{25}$ and later validated for a Malaysian population by Hashim et al. ${ }^{26}$ This measure was developed to assess the perception of parents on OHRQoL of preschool children and composed of 13 items divided between two sections: the Child Impact Section (CIS) and the Family Impact Section (FIS). The CIS has four domains (child symptoms, function, psychological and self-image/social interaction); and FIS had two domains (parent distress and family function). Answers were recorded using a Likert scale to record how often an event had occurred during the life of the child: $0=$ never; $1=$ hardly ever; $2=$ occasionally; 3 = often; 4 = very often; 5 = don't know. The total ECOHIS scores for individual domains were calculated as a simple sum of the response codes, after recoding all 'don't know' responses as missing. For those with up to two missing responses in the CIS or one in the FIS, a score for the missing items was imputed as an average of the remaining items for that section. The CIS and FIS ECOHIS ranged from 0 to 36 and from 0 to 16, respectively, for which higher scores indicated more oral health problems and poorer OHRQOL.

2. Family functioning - 12-item general functioning subscale (GF-12): The GF-12 is a 12 item subscale of the Family Assessment Device (FAD) which is a 60 -item self-report questionnaire developed to measure family functioning. ${ }^{27}$ This measure was assessed among different populations and was proved to be free from cultural bias ${ }^{28}$ with good internal consistency. It can be used to measure the overall family functioning as it correlates highly with all other FAD scales. ${ }^{29}$ This subscale was translated in Mandarin (Chinese version of the GF 12 subscale). ${ }^{30}$ The cut-off score is 2 and any score above 2 will enable clinicians to identify problematic family functioning. ${ }^{27}$

\section{Data collection process}

Families of children eligible for inclusion were approached and invited to participate. The children of the selected school were handed an information leaflet, consent form and questionnaires to take home to their parents/caregivers via their homework diaries. Parents were invited to provide written consent to screen their child's dental health and complete the questionnaires. For the dental caries diagnosis, the participants were examined by standardized evaluators, under the supervision of paediatric dentists. A one-day visit was arranged to the selected school where oral examinations were carried out. The oral screening was performed through disposable dental examination equipment under natural light. Translators (school teachers or supporting staff) assistance was taken in case of language barrier. The filled questionnaires were collected back from the students by the class teachers and were handed over to the researchers.

\section{Data analysis:}

Data were entered using the software Statistical Package for the Social Science (SPSS), v.22.0 for Windows and analysed in terms of descriptive statistics (frequency, mean and standard deviation) for socio-demographic details, clinical information, HRQoL and FAD scores.

The parametric tests were performed to evaluate the associations between the dependent variable (OHRQOL, measured through ECOHIS and family functioning, measured through the GF-12 of the Family Assessment Device) and the independent variable (classification according to the presence of caries). In the comparison of the ECOHIS and GF-12 mean scores, between the groups, the Independent Samples $t$ Test or Analysis of variance (ANOVA) tests were applied. Descriptive, unadjusted analysis was carried out to assess the association of the overall ECOHIS scores with socio-demographics, dental caries status and family functioning. Chi-squared tests, unadjusted and adjusted binary logistic regression models were used to assess the impacts on OHRQoL. Explanatory variables presenting a P value $<0.05$ in the adjusted assessment of covariates were maintained in the final regression model.

\section{Results}

The sample comprised children of Chinese nationality (100\%) with a response rate of $80.5 \%$. The reason for losses were due to failure to obtain written consent and incomplete responses. The mean age of the children was 5 years and almost all of them (97.2\%) were staying with both their parents and half of the total sample (56.3\%) had one sibling. Most of the questionnaires were answered by mothers (64.6\%). Parents' level of education varied from secondary (14.6\%) to tertiary level (85.4\%). Majority of the parents were employed (77.8\%) with monthly income of more than Malaysian Ringgit 5000 (approximately USD 1250) (78.5\%). (Table 1) 
Table 1

Socio-demographic characteristics of participants $(n=144)$

\begin{tabular}{|ll|}
\hline Variables & $\mathrm{n}(\%)$ \\
\hline Total & $144(100)$ \\
\hline Age & $63(43.8)$ \\
\hline 4 years & $39(27.1)$ \\
\hline 5 years & $42(29.1)$ \\
\hline 6 years & \\
\hline Gender & $63(43.7)$ \\
\hline Male & $81(56.3)$ \\
\hline Female & \\
\hline Staying with & $140(97.2)$ \\
\hline Both parents & $3(2.8)$ \\
\hline Single parent & \\
\hline Siblings & $26(18.1)$ \\
\hline No siblings & $81(56.3)$ \\
\hline One sibling & $37(25.7)$ \\
\hline Two or more & \\
\hline Relationship to child & $51(35.4)$ \\
\hline Father & $93(64.6)$ \\
\hline Mother & \\
\hline Monthly income & \\
\hline Up to RM 5000 & $(21.5)$ \\
\hline More than RM5000 & $113(78.5)$ \\
\hline
\end{tabular}

The frequency of the impact on family functioning of the sample according to the parent's answers are presented in Table 2. Overall, compared with pre-established cut-off scores for clinically elevated functioning, sample means on all FAD-GF12 items fell in the nonclinical range score $<2$, indicating normal family functioning. The association of sociodemographic details of the sample with FAD-GF12 is presented in Table 3. 
Table 2

Frequency of the impact on family functioning of children from 4 to 6 years old and their families, according to the parents' answers.

\begin{tabular}{|c|c|c|c|c|c|}
\hline Impact section & $\begin{array}{l}\text { Strongly agree } \\
\text { (SA) } \\
\text { n (\%) }\end{array}$ & $\begin{array}{l}\text { Agree } \\
\text { (A) } \\
\mathrm{n}(\%)\end{array}$ & $\begin{array}{l}\text { Disagree } \\
\text { (D) } \\
\mathrm{n}(\%)\end{array}$ & $\begin{array}{l}\text { Strongly disagree } \\
\text { (SD) } \\
\mathrm{n}(\%)\end{array}$ & $\begin{array}{l}\text { Mean } \\
\text { (SD) }\end{array}$ \\
\hline $\begin{array}{l}\text { Planning family activities is difficult because we } \\
\text { misunderstand each other }\end{array}$ & $4(2.8)$ & $\begin{array}{l}20 \\
(13.9)\end{array}$ & $66(45.8)$ & $53(36.8)$ & $\begin{array}{l}1.81 \\
(0.78)\end{array}$ \\
\hline In times of crisis we can turn to each other for support. & $77(53.5)$ & $\begin{array}{l}65 \\
(45.1)\end{array}$ & $0(0)$ & $2(1.4)$ & $\begin{array}{l}1.49 \\
(0.57)\end{array}$ \\
\hline We cannot talk to each other about the sadness we feel. & $6(4.2)$ & $\begin{array}{l}16 \\
(11.1)\end{array}$ & $79(54.9)$ & $43(29.9)$ & $\begin{array}{l}1.90 \\
(0.75)\end{array}$ \\
\hline Individuals are accepted for what they are. & $89(61.8)$ & $\begin{array}{l}51 \\
(35.4)\end{array}$ & $1(0.7)$ & $3(2.1)$ & $\begin{array}{l}1.43 \\
(0.62)\end{array}$ \\
\hline We avoid discussing our fears and concerns. & $5(3.5)$ & $\begin{array}{l}12 \\
(8.3)\end{array}$ & $84(58.3)$ & $43(29.9)$ & $\begin{array}{l}1.85 \\
(0.70)\end{array}$ \\
\hline We can express feelings to each other. & $62(43.1)$ & $\begin{array}{l}73 \\
(50.7)\end{array}$ & $6(4.2)$ & $3(2.1)$ & $\begin{array}{l}1.65 \\
(0.66)\end{array}$ \\
\hline There are lots of bad feelings in the family. & $1(0.7)$ & $2(1.4)$ & $72(50.0)$ & $69(47.9)$ & $\begin{array}{l}1.55 \\
(0.57)\end{array}$ \\
\hline We feel accepted for what we are. & $60(41.7)$ & $\begin{array}{l}78 \\
(54.2)\end{array}$ & $5(3.5)$ & $1(0.7)$ & $\begin{array}{l}1.63 \\
(0.58)\end{array}$ \\
\hline Making decisions is a problem for our family. & $3(2.1)$ & $\begin{array}{l}12 \\
(8.3)\end{array}$ & $83(57.6)$ & $46(31.9)$ & $\begin{array}{l}1.81 \\
(0.67)\end{array}$ \\
\hline We are able to make decisions about how to solve problems. & $56(38.9)$ & $\begin{array}{l}86 \\
(59.7)\end{array}$ & $2(1.4)$ & $0(0)$ & $\begin{array}{l}1.63 \\
(0.51)\end{array}$ \\
\hline We don't get along well together. & $1(0.7)$ & $2(1.4)$ & $59(41.0)$ & $82(56.9)$ & $\begin{array}{l}1.46 \\
(0.56)\end{array}$ \\
\hline We confide in each other. & $70(48.6)$ & $\begin{array}{l}66 \\
(45.8)\end{array}$ & $4(2.8)$ & $4(2.8)$ & $\begin{array}{l}1.60 \\
(0.68)\end{array}$ \\
\hline
\end{tabular}


Table 3

Association of socio-demographic with GF12 FAD score of the sample.

\begin{tabular}{|c|c|c|c|c|c|}
\hline Variables & FAD Mean (SD) & $\begin{array}{l}\text { Good FAD } \\
\text { n (\%) }\end{array}$ & $\begin{array}{l}\text { Poor FAD } \\
\text { n (\%) }\end{array}$ & $\begin{array}{l}\text { Total } \\
\text { n (\%) }\end{array}$ & $p$-value \\
\hline Total & $1.18(0.38)$ & $117(81.2)$ & $27(18.8)$ & $144(100)$ & \\
\hline \multicolumn{6}{|l|}{ Age } \\
\hline 4 years & $1.17(0.38)$ & $52(82.5)$ & $11(17.5)$ & $63(100)$ & 0.929 \\
\hline 5 years & $1.21(0.40)$ & $31(79.5)$ & $8(20.5)$ & $39(100)$ & \\
\hline 6 years & $1.19(0.39)$ & $34(81.0)$ & $8(19.0)$ & $42(100)$ & \\
\hline \multicolumn{6}{|l|}{ Gender } \\
\hline Male & $1.16(0.36)$ & $53(84.1)$ & $10(15.9)$ & $63(100)$ & 0.439 \\
\hline Female & $1.21(0.41)$ & $64(79.0)$ & $17(21.0)$ & $81(100)$ & \\
\hline \multicolumn{6}{|l|}{ Staying with } \\
\hline Both parents & $1.19(0.39)$ & $114(81.4)$ & $26(18.6)$ & $140(100)$ & 0.521 \\
\hline Single parent & $1.33(0.57)$ & $2(66.7)$ & $1(33.3)$ & $3(100)$ & \\
\hline \multicolumn{6}{|l|}{ Siblings } \\
\hline No siblings & $1.23(0.43)$ & $20(77.0)$ & $6(23.0)$ & $26(100)$ & 0.352 \\
\hline One sibling & $1.21(0.41)$ & $64(79.0)$ & $17(21.0)$ & $81(100)$ & \\
\hline Two or more & $1.11(0.31)$ & $14(37.8)$ & $23(62.2)$ & $37(100)$ & \\
\hline \multicolumn{6}{|l|}{ Relationship to child } \\
\hline Father & $1.10(0.30)$ & $46(90.2)$ & $5(9.8)$ & $51(100)$ & 0.042 \\
\hline Mother & $1.24(0.42)$ & $71(76.3)$ & $22(23.7)$ & $93(100)$ & \\
\hline \multicolumn{6}{|l|}{ Monthly income } \\
\hline Lower than RM 5000 & $1.19(0.40)$ & $25(80.6)$ & $6(19.4)$ & $31(100)$ & 0.923 \\
\hline RM 5000 and above & $1.19(0.39)$ & $92(81.4)$ & $21(18.6)$ & $113(100)$ & \\
\hline
\end{tabular}

Significant findings were noted with parents' relationship to child with family functioning ( $p$ value 0.042 ). The association of sociodemographic and FAD-GF12 score with caries status of the sample is presented in Table 4. Statistical significance was noted with number of siblings and the mean FAD-GF12 Score. The ECOHIS questionnaire were answered by parents, The ECOHIS scores ranged from 0 to 27 with a 0.52 mean $(S D=0.68)$. The highest score of impacts reported was 20 on the CIS and 12 on FIS. The result from this study observed that less than half of children (41.7\%) were reported to have suffered from teeth, mouth and jaw pain in the child impact section. The most frequently reported was the item related to "been irritable or frustrated" (58.3\%) followed by items related to "missed nursery, kindergarten or school" (50.7\%) and "had trouble of sleeping" (44.5\%). In the family impact section, the most frequently reported was the item related to "been upset" (35.5\%) (Table 5). When the mean overall score was analysed, it was observed that dental caries had a negative impact on OHRQoL $(P=0.014)$. Considering each domain, there was a significant difference in scores between the levels of dental caries regarding all domains included in the CIS and FIS $(P<0.001)$ except for DS $(P=0.580)$ and DFF $(P=0.006)($ Table 6$)$. The association of socio-demographic, family functioning and caries status with ECOHIS $\leq 1$ and ECOHIS $\geq 1$ scores of the sample is presented in Table 7 . The univariate analysis showed that the following variables were statistically significant: FAD-GF12 $(P=0.001)$ and dental caries status $(P=<$ 0.001). 
Table 4

Distribution of caries status on socio-demographic characteristics $(n=149)$

\begin{tabular}{|lllll|}
\hline Socio-demographic & $\begin{array}{l}\text { Caries free } \\
\mathbf{n}(\%)\end{array}$ & $\begin{array}{l}\text { Caries } \\
\mathbf{n}(\%)\end{array}$ & $\begin{array}{l}\text { Total } \\
\mathbf{n}(\%)\end{array}$ & p-value \\
\hline Total & $73(50.7)$ & $71(49.3)$ & $144(100)$ & \\
\hline Age & & & & \\
\hline 4 years & $32(50.8)$ & $31(49.2)$ & $63(100)$ & 0.993 \\
\hline 5 years & $20(51.3)$ & $19(48.7)$ & $39(100)$ & \\
\hline 6 years & $21(50.0)$ & $21(50.0)$ & $42(100)$ & \\
\hline Gender & & & & \\
\hline Male & $32(50.8)$ & $31(49.2)$ & $63(100)$ & 0.983 \\
\hline Female & $41(50.6)$ & $40(49.4)$ & $81(100)$ & \\
\hline Staying with & & & & \\
\hline Both parents & $70(50.0)$ & $70(50.0)$ & $140(100)$ & 0.568 \\
\hline Single parent & $3(75.0)$ & $1(25.0)$ & $4(100)$ & \\
\hline Siblings & & & & \\
\hline No siblings & $13(50.0)$ & $13(50.0)$ & $26(100)$ & 0.050 \\
\hline One sibling & $35(43.2)$ & $46(56.8)$ & $81(100)$ & \\
\hline Two or more & $25(67.6)$ & $12(44.4)$ & $37(100)$ & \\
\hline Relationship to child & & & & \\
\hline Father & $28(54.9)$ & $23(45.1)$ & $51(100)$ & 0.455 \\
\hline Mother & $45(48.4)$ & $48(51.6)$ & $93(100)$ & \\
\hline Monthly income & & & & \\
\hline Up to RM 5000 & & & & \\
\hline More than RM5000 & $56(49.6)$ & $57(50.4)$ & $113(100)$ & \\
\hline Family Functioning: GF 12 & & & & \\
\hline Good FAD & & & & \\
\hline Poor FAD & & & & \\
\hline
\end{tabular}


Table 5

Frequency of the impact on quality of life of children from 4 to 6 years old and their families, according to the parents' answers, because of dental caries

\begin{tabular}{|c|c|c|c|c|c|c|c|c|}
\hline Impact section & Domains & $\begin{array}{l}\text { Never } \\
\mathrm{n}(\%)\end{array}$ & $\begin{array}{l}\text { Hardly } \\
\text { ever } \\
\text { n (\%) }\end{array}$ & $\begin{array}{l}\text { Occasionally } \\
\mathrm{n}(\%)\end{array}$ & $\begin{array}{l}\text { Often } \\
\mathrm{n}(\%)\end{array}$ & $\begin{array}{l}\text { Very } \\
\text { often } \\
n(\%)\end{array}$ & $\begin{array}{l}\text { Don't } \\
\text { know } \\
\text { n (\%) }\end{array}$ & $\begin{array}{l}\text { Mean } \\
\text { (SD) }\end{array}$ \\
\hline \multicolumn{9}{|l|}{ Children impact section } \\
\hline $\begin{array}{l}\text { 1. How often does your child... Feel teeth, mouth and } \\
\text { jaw pain? }\end{array}$ & DS & $\begin{array}{l}84 \\
(58.3)\end{array}$ & $\begin{array}{l}45 \\
(31.3)\end{array}$ & $15(10.4)$ & 0 & 0 & 0 & $\begin{array}{l}0.52 \\
(0.68)\end{array}$ \\
\hline \multicolumn{9}{|c|}{ How often does your child...because of teeth problems or dental treatments? } \\
\hline 2. have difficulties to have hot or cold drinks & DL & $\begin{array}{l}100 \\
(69.4)\end{array}$ & $\begin{array}{l}35 \\
(24.3)\end{array}$ & $9(6.3)$ & 0 & 0 & 0 & $\begin{array}{l}0.37 \\
(0.60)\end{array}$ \\
\hline 3. have difficulty to eat certain types of food & DL & $\begin{array}{l}97 \\
(67.4)\end{array}$ & $\begin{array}{l}32 \\
(22.2)\end{array}$ & $12(8.3)$ & $\begin{array}{l}3 \\
(2.1)\end{array}$ & 0 & 0 & $\begin{array}{l}0.45 \\
(0.89)\end{array}$ \\
\hline 4. have difficulties to pronounce any word & DL & $\begin{array}{l}89 \\
(61.8)\end{array}$ & $\begin{array}{l}36 \\
(25.0)\end{array}$ & $17(11.8)$ & $\begin{array}{l}2 \\
(1.4)\end{array}$ & 0 & 0 & $\begin{array}{l}0.53 \\
(0.75)\end{array}$ \\
\hline 5. missed nursery, kindergarten or school & DL & $\begin{array}{l}71 \\
(49.3)\end{array}$ & $\begin{array}{l}30 \\
(20.8)\end{array}$ & $41(28.5)$ & $\begin{array}{l}1 \\
(0.7)\end{array}$ & $\begin{array}{l}1 \\
(0.7)\end{array}$ & 0 & $\begin{array}{l}0.83 \\
(0.92)\end{array}$ \\
\hline 6. have difficulty to sleep & DP & $\begin{array}{l}87 \\
(60.4)\end{array}$ & $\begin{array}{l}43 \\
(29.9)\end{array}$ & $9(6.3)$ & $\begin{array}{l}4 \\
(2.8)\end{array}$ & $\begin{array}{l}1 \\
(0.7)\end{array}$ & 0 & $\begin{array}{l}0.53 \\
(0.78)\end{array}$ \\
\hline 7. been irritable or frustrated & DP & $\begin{array}{l}60 \\
(41.7)\end{array}$ & $\begin{array}{l}31 \\
(21.5)\end{array}$ & $41(28.5)$ & $\begin{array}{l}10 \\
(6.9)\end{array}$ & 2 & 0 & $\begin{array}{l}1.05 \\
(1.05)\end{array}$ \\
\hline 8. avoid smiling or laughing & DAIS & $\begin{array}{l}84 \\
(58.3)\end{array}$ & $\begin{array}{l}45 \\
(31.3)\end{array}$ & $12(8.3)$ & $\begin{array}{l}3 \\
(2.1)\end{array}$ & 0 & 0 & $\begin{array}{l}0.54 \\
(1.18)\end{array}$ \\
\hline 9. had trouble of sleeping & DAIS & $\begin{array}{l}80 \\
(55.6)\end{array}$ & $\begin{array}{l}41 \\
(28.5)\end{array}$ & $19(13.2)$ & $\begin{array}{l}4 \\
(2.8)\end{array}$ & 0 & 0 & $\begin{array}{l}0.63 \\
(0.81)\end{array}$ \\
\hline \multicolumn{9}{|l|}{ Family impact section } \\
\hline \multicolumn{9}{|c|}{ How often have you or another family member... because of teeth problems or dental treatment of your child? } \\
\hline 10. been upset & DAP & $\begin{array}{l}93 \\
(64.6)\end{array}$ & $\begin{array}{l}39 \\
(27.1)\end{array}$ & $8(5.6)$ & $\begin{array}{l}4 \\
(2.8)\end{array}$ & 0 & 0 & $\begin{array}{l}0.47 \\
(0.72)\end{array}$ \\
\hline 11. felt guilty & DAP & $\begin{array}{l}101 \\
(70.1)\end{array}$ & $\begin{array}{l}37 \\
(25.7)\end{array}$ & $4(2.8)$ & $\begin{array}{l}2 \\
(1.4)\end{array}$ & 0 & 0 & $\begin{array}{l}0.35 \\
(0.61)\end{array}$ \\
\hline 12. Taken time off from work & DFF & $\begin{array}{l}103 \\
(71.5)\end{array}$ & $\begin{array}{l}30 \\
(20.8)\end{array}$ & $11(7.6)$ & 0 & 0 & 0 & $\begin{array}{l}0.36 \\
(0.62)\end{array}$ \\
\hline $\begin{array}{l}\text { 13. How often has your child had dental problems or } \\
\text { dental treatment which caused financial impact to } \\
\text { your family? }\end{array}$ & DFF & $\begin{array}{l}107 \\
(74.3)\end{array}$ & $\begin{array}{l}32 \\
(22.2)\end{array}$ & $5(3.5)$ & 0 & 0 & 0 & $\begin{array}{l}0.29 \\
(0.52)\end{array}$ \\
\hline
\end{tabular}


Table 6

Association of ECOHIS scores with caries status of the sample.

\begin{tabular}{|c|c|c|c|c|c|c|c|c|c|}
\hline & $\begin{array}{l}\text { DS } \\
\text { Mean (SD) }\end{array}$ & $\begin{array}{l}\text { DL } \\
\text { Mean (SD) }\end{array}$ & $\begin{array}{l}\text { DP } \\
\text { Mean (SD) }\end{array}$ & $\begin{array}{l}\text { DAIS } \\
\text { Mean (SD) }\end{array}$ & DAP & DFF & $\begin{array}{l}\text { Child } \\
\text { impact } \\
\text { section }\end{array}$ & $\begin{array}{l}\text { Family } \\
\text { impact } \\
\text { section }\end{array}$ & $\begin{array}{l}\text { ECOHIS } \\
\text { Overall }\end{array}$ \\
\hline $\begin{array}{l}\text { Overall } \\
(n=144)\end{array}$ & $0.52(0.68)$ & $\begin{array}{l}0.54 \\
(0.55)\end{array}$ & $\begin{array}{l}0.79 \\
(0.81)\end{array}$ & $\begin{array}{l}0.57 \\
(0.71)\end{array}$ & $\begin{array}{l}0.41 \\
(0.63)\end{array}$ & $\begin{array}{l}0.32 \\
(0.54)\end{array}$ & $\begin{array}{l}0.60 \\
(0.54)\end{array}$ & $\begin{array}{l}0.37 \\
(0.53)\end{array}$ & $\begin{array}{l}0.53 \\
(0.49)\end{array}$ \\
\hline $\begin{array}{l}\text { Caries } \\
(n=71)\end{array}$ & $0.55(0.68)$ & $\begin{array}{l}0.77 \\
(0.58)\end{array}$ & $\begin{array}{l}1.05 \\
(0.85)\end{array}$ & $\begin{array}{l}0.79 \\
(0.79)\end{array}$ & $\begin{array}{l}0.60 \\
(0.67)\end{array}$ & $\begin{array}{l}0.45 \\
(0.59)\end{array}$ & $\begin{array}{l}0.81 \\
(0.57)\end{array}$ & $\begin{array}{l}0.52 \\
(0.57)\end{array}$ & $\begin{array}{l}0.72 \\
(0.50)\end{array}$ \\
\hline $\begin{array}{l}\text { Free of } \\
\text { caries } \\
(n=73)\end{array}$ & $0.49(0.68)$ & $\begin{array}{l}0.32 \\
(0.42)\end{array}$ & $\begin{array}{l}0.53 \\
(0.68)\end{array}$ & $\begin{array}{l}0.34 \\
(0.55)\end{array}$ & $\begin{array}{l}0.24 \\
(0.52)\end{array}$ & $\begin{array}{l}0.20 \\
(0.46)\end{array}$ & $\begin{array}{l}0.39 \\
(0.42)\end{array}$ & $\begin{array}{l}0.22 \\
(0.44)\end{array}$ & $\begin{array}{l}0.34 \\
(0.39)\end{array}$ \\
\hline $\begin{array}{l}\text { Mean } \\
\text { diff. } \\
(95 \% \mathrm{Cl})\end{array}$ & $\begin{array}{l}0.06 \\
(-0.16,0.28)\end{array}$ & $\begin{array}{l}0.45 \\
(0.28,0.61)\end{array}$ & $\begin{array}{l}0.52 \\
(0.26,0.77)\end{array}$ & $\begin{array}{l}0.45 \\
(0.22,0.67)\end{array}$ & $\begin{array}{l}0.36 \\
(0.16,0.55)\end{array}$ & $\begin{array}{l}0.24 \\
(0.07,0.41)\end{array}$ & $\begin{array}{l}0.42 \\
(0.25,0.58)\end{array}$ & $\begin{array}{l}0.30 \\
(0.13,0.47)\end{array}$ & $\begin{array}{l}0.38 \\
(0.23,0.53)\end{array}$ \\
\hline $\begin{array}{l}t- \\
\text { statistics } \\
\text { (df) }\end{array}$ & $\begin{array}{l}0.54(147) \\
a\end{array}$ & $5.35(147)$ & 4.09 (147) & $4.01(147)$ & $3.63(147)$ & $2.80(147)$ & $5.10(147)$ & $3.59(147)$ & $5.18(147)$ \\
\hline$p$-value & 0.580 & $<0.001$ & $<0.001$ & $<0.001$ & $<0.001$ & 0.006 & $<0.001$ & $<0.001$ & 0.014 \\
\hline \multicolumn{10}{|c|}{ a Equal variance assumed } \\
\hline
\end{tabular}


Table 7

Association of exploratory variables with ECOHIS $\leq 1$ and ECOHIS $\geq 1$ scores of the sample.

\begin{tabular}{|c|c|c|c|c|c|}
\hline Variables & $\begin{array}{l}\text { ECOHIS Scores } \\
\text { Mean (SD) }\end{array}$ & $\begin{array}{l}\text { ECOHIS } \leq 1 \\
n(\%)\end{array}$ & $\begin{array}{l}\text { ECOHIS } \geq 1 \\
\mathrm{n}(\%)\end{array}$ & $\begin{array}{l}\text { Total } \\
\text { n (\%) }\end{array}$ & $p$-value \\
\hline Total & $1.72(0.44)$ & 104 (72.2) & $40(27.8)$ & $144(100)$ & \\
\hline \multicolumn{6}{|l|}{ Age } \\
\hline 4 years & $0.45(0.47)$ & $42(66.6)$ & $21(33.4)$ & $63(100)$ & 0.125 \\
\hline 5 years & $0.65(0.51)$ & $33(84.6)$ & $6(14.4)$ & $39(100)$ & \\
\hline 6 years & $0.53(0.50)$ & $29(69.0)$ & $13(31.0)$ & $42(100)$ & \\
\hline \multicolumn{6}{|l|}{ Gender } \\
\hline Male & $0.55(0.51)$ & $46(73.0)$ & $17(27.0)$ & $63(100)$ & 0.501 \\
\hline Female & $0.51(0.48)$ & $58(71.6)$ & $23(28.4)$ & $81(100)$ & \\
\hline \multicolumn{6}{|l|}{ Staying with } \\
\hline Both parents & $0.54(0.50)$ & 102 (72.9) & $38(27.1)$ & $140(100)$ & 0.270 \\
\hline Single parent & $0.07(0.13)$ & $1(25.0)$ & $3(75.0)$ & $4(100)$ & \\
\hline \multicolumn{6}{|l|}{ Siblings } \\
\hline No siblings & $0.47(0.42)$ & $18(69.2)$ & $8(30.8)$ & $26(100)$ & 0.378 \\
\hline One sibling & $0.51(0.53)$ & $56(69.1)$ & $25(30.9)$ & $81(100)$ & \\
\hline Two or more & $0.61(0.45)$ & $30(81.0)$ & 7 (18.9) & $37(100)$ & \\
\hline \multicolumn{6}{|l|}{ Relationship to child } \\
\hline Father & $0.42(0.43)$ & $34(66.7)$ & $17(33.3)$ & $51(100)$ & 0.182 \\
\hline Mother & $0.59(0.52)$ & $70(75.3)$ & $23(24.7)$ & $93(100)$ & \\
\hline \multicolumn{6}{|l|}{ Monthly income } \\
\hline Up to RM 5000 & $0.53(0.57)$ & $20(64.5)$ & $11(35.5)$ & $31(100)$ & 0.280 \\
\hline More than RM5000 & $0.53(0.47)$ & $84(74.3)$ & $29(25.7)$ & $113(100)$ & \\
\hline \multicolumn{6}{|c|}{ Family Functioning: GF 12} \\
\hline Good FAD & $0.46(0.47)$ & 79 (67.5) & $38(32.5)$ & $117(100)$ & 0.001 \\
\hline Poor FAD & $0.82(0.52)$ & $25(92.6)$ & $2(7.4)$ & $27(100)$ & \\
\hline \multicolumn{6}{|l|}{ Dental caries status } \\
\hline Caries free & $0.33(0.39)$ & $43(58.9)$ & $30(41.1)$ & $73(100)$ & $<0.001$ \\
\hline Caries & $0.73(0.51)$ & $61(85.9)$ & $10(14.1)$ & $71(100)$ & \\
\hline
\end{tabular}

The bivariate regression analysis (Table 8) showed that family functioning and dental caries status were associated with the outcome. The odds suggested, children with Poor family functioning were six times more likely to have poor OHRQoL as compared to those with good family functioning. In contrast, children without dental caries were four times more likely to have better OHRQoL. Family functioning can be a mediator for the association between dental caries and OHRQoL. After adjusting against family functioning the odds for dental caries changed. Before adjusting, children without caries were four times more likely to have better OHRQoL as compared to those with caries. After adjusting it with family functioning, the odds were decreased (3.17) suggesting that poor family functioning can lower the OHRQoL. 
Table 8

Unadjusted and Adjusted odds of the association between ECOHIS scores and exploratory variables; Binary regression analysis: Level 3, adjusted for Level 1,2,4 and within the same level.

\begin{tabular}{|c|c|c|c|c|c|c|}
\hline \multirow[b]{2}{*}{ Variables } & \multicolumn{3}{|c|}{ Unadjusted } & \multicolumn{3}{|c|}{ Adjusted } \\
\hline & OR & $95 \% \mathrm{Cl}$ & p-value & OR & $95 \% \mathrm{Cl}$ & p-value \\
\hline \multicolumn{7}{|c|}{ Level 1: Demographic variables } \\
\hline \multicolumn{7}{|l|}{ Age } \\
\hline 4 years & 1.00 & & 0.137 & 1.00 & & 0.142 \\
\hline 5 years & 2.75 & $(0.99-7.59)$ & & 2.76 & $(0.982-7.763)$ & \\
\hline 6 years & 1.11 & $(0.48-2.57)$ & & 1.09 & $(0.464-2.601)$ & \\
\hline \multicolumn{7}{|l|}{ Gender } \\
\hline Male & 1.07 & $(0.51-2.24)$ & 0.851 & 1.15 & $(0.54-2.45)$ & 0.714 \\
\hline Female & 1.00 & & & 1.00 & & \\
\hline \multicolumn{7}{|c|}{ Level 2: Socioeconomic variable } \\
\hline \multicolumn{7}{|l|}{ Staying with } \\
\hline Both parents & 5.36 & $(0.47-60.93)$ & 0.175 & 9.14 & $(0.58-143.5)$ & 0.115 \\
\hline Single parent & 1.00 & & & 1.00 & & \\
\hline \multicolumn{7}{|l|}{ Siblings } \\
\hline No siblings & 1.00 & & 0.385 & 1.00 & & 0.236 \\
\hline One sibling & 0.99 & $(0.38-2.59)$ & & 1.02 & $(0.38-2.76)$ & \\
\hline Two or more & 1.90 & $(0.59-6.14)$ & & 2.29 & $(0.69-7.63)$ & \\
\hline \multicolumn{7}{|l|}{ Relationship to child } \\
\hline Father & 0.65 & $(0.31-1.39)$ & 0.272 & 0.77 & $(0.35-1.65)$ & 0.505 \\
\hline Mother & 1.00 & & & 1.00 & & \\
\hline \multicolumn{7}{|l|}{ Monthly income } \\
\hline Up to RM 5000 & 1.00 & & 0.282 & 1.00 & & 0.260 \\
\hline More than RM5000 & 1.59 & $(0.68-3.72)$ & & 1.65 & $(0.68-3.97)$ & \\
\hline \multicolumn{7}{|l|}{ Level 3: } \\
\hline \multicolumn{7}{|c|}{ Family Functioning: GF 12} \\
\hline Good FAD & 1.00 & & 0.018 & & & \\
\hline Poor FAD & 6.01 & $(1.35-26.7)$ & & & & \\
\hline \multicolumn{7}{|l|}{ Level 4: } \\
\hline \multicolumn{7}{|l|}{ Dental caries status } \\
\hline Caries free & 4.25 & $(1.88-9.61)$ & $<0.001$ & 3.17 & $(1.32-7.63)$ & 0.01 \\
\hline Caries & 1.00 & & & 1.00 & & \\
\hline
\end{tabular}

\section{Discussion}

This cross-sectional study focused on Chinese ethnicity, is the first study to observe family functioning as a mediating factor of diseasespecific OHRQOL among pre-school children with childhood dental caries in Malaysia. Understanding of these impacts will aid the clinicians and researchers evaluate oral health needs, ascertain priorities of care and gauge the outcomes of treatments approaches. 
Overall good family functioning and OHRQoL were observed among 4 to 6-year-old pre-school Chinese children in this study. The reason could be the socioeconomic factors of the sample, that only included pre-school children from an international school setting reflecting of high socioeconomic background. More than three-fourth of the parents had monthly income of above twelve hundred USD and almost all the children were living with both parents with small family structure. Chinese traditional culture is known for its strong and distinct family ethics, as part of this principled code of conduct in fostering children as their responsibilities, and in turn it ponders contentment and happiness.

The structure of the family is also associated with children's dental health. In contrast to previous findings, this study found a significant association between family functioning and childhood dental caries. Almost all the children from poorer functioning families had dental decay than children from normal functioning families. ${ }^{9,31}$ Significant findings were noted with parents relationship to child with family functioning, it indicates the possibility that better family functioning is reported by fathers that is reflective of dominant role of males in Chinese culture. ${ }^{32}$

The same children were also more likely to have poor OHRQoL. Quality of life is impacted by oral health under physical, social and psychological domains. ${ }^{33}$ In general similar association was seen with other studies that showed a relationship between family functioning and $\mathrm{QOL}^{34-36}$ we found a statistically significant correlation between parental report of their family functioning and perception of their child's OHRQoL. The negative impact of dental caries on children's OHRQoL is supported by previously reported findings. These impacts of oral pain, chewing and sleeping difficulties, changes in behaviours and decrease in school performance. ${ }^{37-39}$

Findings of this study confirms the association between the presence of dental caries and OHRQoL in young children in support to the previous studies. ${ }^{14,16,40}$ Several studies have verified the children's parents responses for the OHRQoL, ${ }^{13-16}$ indicated that the dental caries' impact on children's life is frequently related to the symptoms, limitations and psychological aspects. The finding of this study support the previous findings with significance observed in all domains except in symptom domain.

The lack of association between symptom domain and caries status could be explained by the levels of caries severity observed during clinical examination. Almost all the children in this study had low severity that could reflect on child's perception of pain in symptoms domain. Dental caries is marked as slow progressing disease with relatively stable clinical signs (white or light brown spots). During this stage the symptoms are not perceived by lay individuals as an indicator of disease activity or latency. The symptoms are more recognizable as the disease progresses (brown spots with slight or moderate pain). ${ }^{41}$

In relation to the previous study finding, sociodemographic characteristics does not show substantial association with OHRQoL. ${ }^{42}$ However in contrast to previous studies which reported families who have low socioeconomic status were more likely to rate their child's oral health 'worse than other children, ${ }^{43}$ this could be due to high SES for majority of our sample. Supported by various researchers and policy makers, common risk factor approach proves to be the most effective strategy to be incorporated for the overall well-being of individuals. ${ }^{44,45}$ Feldens et al. ${ }^{45}$ established the relationship between healthy dietary habits and decreased caries incidence through a randomized control trial.

Locker proposed that the link between oral disease and health-related quality of life outcomes is interceded by personal and environmental factors. ${ }^{46}$ the findings of this study shows strong association between family functioning and caries status with OHRQoL. Ungar explained the construct of resilience among children who face adversity, good family functioning can be conceptualized as a relational protective process that predict positive outcomes. ${ }^{47}$ Family functioning medicate an environment for the development of dental caries which in turn would result in compromised OHRQoL.

The strengths of this study was evident by the use of reliable and valid instruments to assess OHRQoL and family functioning. The measures were reported to have good psychometric properties, and they gain attention from their source in theoretical models. However, some probable limitations should be taken into consideration, that includes our sample being from one ethnic group and belonging to affluent social class thus indicating for the limited generalizability. The cross-sectional nature of study design was one of the limitations associated with this research. Another concern could be of using self-report methods that rely on parents' perceptions and beliefs and they could be diverse from the actual behaviours. ${ }^{48}$ Alternative possible limitation might be the 'Hawthorn effect' (parents' reactivity to modify their behaviour in order to avoid embarrassment). ${ }^{49}$

\section{Conclusion}

Findings of this study indicate that a potentially important variable to consider in caries preventive programmes include components to improve family functioning which in turns effects the quality of life. A cohort study with a larger sample size should be the next step forward towards better understanding of mediators of OHRQoL in the Malaysian context. 


\section{Abbreviations}

OHRQOL

Oral health related quality of life

ECOHIS

Early Childhood Oral Health Impact Scale

FAD-GF12

Family functioning - 12-item general functioning subscale

\section{Declarations}

Ethics approval and consent to participate

Ethics approval was obtained from institutional Joint Research and Ethics Committee, International Medical University, Malaysia (number 373/2016). Written consent to participate was obtained from parents prior to data collection.

\section{Consent for publication}

Consent for publication was obtained along with the written consent to participate in this study from parents/guardians of pre-school children.

\section{Availability of data and materials}

All data are held by School of Dentistry, International Medical University under data storage guidelines.

\section{Competing interests}

The author declares that they have no competing interests.

\section{Funding}

The source of funding is by the institutional Joint Research and Ethics Committee, International Medical University, Malaysia (number $373 / 2016)$.

\section{Authors' contributions}

SB, AMA and APKH contributed to the conception and design of the work, the acquisition and interpretation of data, and initial and subsequent drafts of the manuscript. SB, NSA and MGB contributed to the analysis and interpretation of the data, and the initial and subsequent drafts of the manuscript. All authors read and approved the final manuscript.

\section{Acknowledgements}

This study was supported in part by the Joint Ethics committee at International Medical University, Malaysia (number 373/2016) and The Chinese Taipei School, Kuala Lumpur, Malaysia.

\section{Authors' information (optional)}

1. International Medical University, Division of Children and Community Oral Health, School of Dentistry, Kuala Lumpur, Malaysia.

2. Bilal, N.S. Andiesta, M.G. Babar \& A.P.K. Heng

3. King Khalid University, Department of Paediatric Dentistry \& Orthodontics, College of Dentistry, Kingdom of Saudi Arabia.

A.M. Abdulla

\section{References}

1. Holst D, Schuller AA, Aleksejuniene J, Eriksen HM. Caries in populations - a theoretical, causal approach. Eur J Oral Sci. 2001 Jun 1;109(3):143-8.

2. Kawashita Y, Kitamura M, Saito T. Early childhood caries. Int J Dent. 2011 Oct 10;2011:725320.

3. Narvey A, Shwart L. Early childhood dental disease - what's in a name? J Can Dent Assoc. 2007 Dec;73(10):929-30. 
4. Harris R, Nicoll A, Adair P, health CP-C dental, 2004 undefined. Risk factors for dental caries in young children: a systematic review of the literature. who.int.

5. van Palenstein Helderman WH, Soe W, van 't Hof MA. Risk Factors of Early Childhood Caries in a Southeast Asian Population. J Dent Res. 2006 Jan 11;85(1):85-8.

6. Schroth RJ, Halchuk S, Star L. Prevalence and risk factors of caregiver reported Severe Early Childhood Caries in Manitoba First Nations children: results from the RHS Phase 2 (2008-2010). Int J Circumpolar Health. 2013 Jan 31;72(1):21167.

7. Duijster D, Verrips GHW, van Loveren C. The role of family functioning in childhood dental caries. Community Dent Oral Epidemiol. 2014 Jun 1;42(3):193-205.

8. Epstein NB, Ryan CE, Bishop DS, Miller IW, Keitner G. The McMaster model: A view of healthy family functioning. In: Normal family processes: Growing diversity and complexity. 3rd ed. New York, NY, US: The Guilford Press; 2003. p. 581-607.

9. Hooley M, Skouteris H, Boganin C, Satur J, Kilpatrick N. Parental influence and the development of dental caries in children aged 0-6 years: A systematic review of the literature. J Dent. 2012 Nov;40(11):873-85.

10. Walsh F. Family Resilience: A Framework for Clinical Practice. Fam Process. 2003 Mar 1;42(1):1-18.

11. Wan Othman W, Abd Muttalib K, Mohamad A, Tan B-S, Zurina A, Che Salleh N, et al. The National Oral Health Survey of Preschool Children 2005 (NOHPS 2005) Oral Health Status and Treatment Needs. Kuala Lumpur; 2005.

12. Health Information Management System, Malaysia. Oral Health Subsystem. Kuala Lumpur; 2012.

13. de Andrade LHR, Buczynski AK, Raggio Luiz R, Castro GF, Pomarico Ribeiro de Souza I. Impacto de la salud oral en la calidad de vida de los niños pre-escolares:: percepción de los responsables. Acta odontológica Venez ISSN 00016365, Vol 49, № 4, 2011, págs 15-16. 2011;49(4):15-6.

14. Wong HM, McGrath CPJ, King NM, Lo ECM. Oral Health-Related Quality of Life in Hong Kong Preschool Children. Caries Res. 2011;45(4):370-6.

15. Kramer PF, Feldens CA, Helena Ferreira S, Bervian J, Rodrigues PH, Peres MA. Exploring the impact of oral diseases and disorders on quality of life of preschool children. Community Dent Oral Epidemiol. 2013 Aug 1;41(4):327-35.

16. Abanto J, Carvalho TS, Mendes FM, Wanderley MT, Bönecker M, Raggio DP. Impact of oral diseases and disorders on oral health-related quality of life of preschool children. Community Dent Oral Epidemiol. 2011 Apr 1;39(2):105-14.

17. Zubrick S, Australia. Department of Family and Community Services. AA, Silburn SR, Vimpani G. Indicators of social and family functioning. Canberra: Dept. of Family and Community Services; 2000.

18. Wen LM, Simpson JM, Baur LA, Rissel C, Flood VM. Family Functioning and Obesity Risk Behaviors: Implications for Early Obesity Intervention. Obesity. 2011 Jun 2;19(6):1252-8.

19. Renzaho AMN, de Silva-Sanigorski A. The importance of family functioning, mental health and social and emotional well-being on child oral health. Child Care Health Dev. 2014 Jul 1;40(4):543-52.

20. Tang C, Quinonez RB, Hallett K, Lee JY, Kenneth Whitt J. Examining the association between parenting stress and the development of early childhood caries. Community Dent Oral Epidemiol. 2005 Dec 1;33(6):454-60.

21. Bonanato K, Paiva SM, Pordeus IA, Ramos-Jorge ML, Barbabela D, Allison PJ. Relationship between Mothers' Sense of Coherence and Oral Health Status of Preschool Children. Caries Res. 2009;43(2):103-9.

22. Lenčová E, Pikhart H, Broukal Z, Tsakos G. Relationship between parental locus of control and caries experience in preschool children cross-sectional survey. BMC Public Health. 2008 Dec 12;8(1):208.

23. Lewison G, Kumar S, Wong C-Y, Roe P, Webber R. The contribution of ethnic groups to Malaysian scientific output, 1982-2014, and the effects of the new economic policy. Scientometrics. 2016 Dec 1;109(3):1877-93.

24. WHO | Oral health surveys: basic methods - 5th edition. WHO. São Paulo, Brazil: World Health Organization; 2018.125 p.

25. Pahel BT, Rozier RG, Slade GD. Parental perceptions of children's oral health: the Early Childhood Oral Health Impact Scale (ECOHIS). Health Qual Life Outcomes. 2007 Jan 30;5:6.

26. Hashim AN, Yusof ZYM, Esa R. The Malay version of the Early Childhood Oral Health Impact Scale (Malay-ECOHIS) - assessing validity and reliability. Health Qual Life Outcomes. 2015;13(1).

27. Epstein N, Baldwin L. The McMaster family assessment device. Marital Fam Ther. 1983;

28. Mansfield AK, Keitner GI, Dealy J. The Family Assessment Device: An Update. Fam Process. 2015 Mar;54(1):82-93.

29. Shek DTL. The General Functioning Scale of the Family Assessment Device: Does it work with Chinese adolescents? J Clin Psychol. 2001 Dec;57(12):1503-16. 
30. Wo S, Lai P, Ong L, Low W, Wu D, AM N, et al. Factorial Validation of the Chinese General Functioning Subscale (Gf-12) Of The Family Assessment Device in Malaysia. J Heal Transl Med. 2018;21(2):23-30.

31. Hallett K, O’Rourke P. Social and behavioural determinants of early childhood caries. Aust Dent J. 2003 Mar 1;48(1):27-33.

32. Hong C, Baharudin R, Social ZH-PJ of, 2012 undefined. Fathers' Parenting Styles in Chinese Families in Urban Malaysia. JSSH-Pertanika J Soc Sci Humanit. 2012;20(4):1019-34.

33. Tesch FC, Oliveira BH de, Leão A. Equivalência semântica da versão em português do instrumento Early Childhood Oral Health Impact Scale. Cad Saude Publica. 2008 Aug;24(8):1897-909.

34. Curt LaFrance Jr. W, Alosco ML, Davis JD, Tremont G, Ryan CE, Keitner GI, et al. Impact of family functioning on quality of life in patients with psychogenic nonepileptic seizures versus epilepsy. Epilepsia. 2011 Feb 1;52(2):no-no.

35. Speechley KN, Ferro MA, Camfield CS, Huang W, Levin SD, Smith M Lou, et al. Quality of life in children with new-onset epilepsy: a 2-year prospective cohort study. Neurology. 2012 Oct 9;79(15):1548-55.

36. Austin JK, Perkins SM, Johnson CS, Fastenau PS, Byars AW, deGrauw TJ, et al. Self-esteem and symptoms of depression in children with seizures: Relationships with neuropsychological functioning and family variables over time. Epilepsia. 2010 Oct 1;51(10):2074-83.

37. Feitosa S, Colares V, Pinkham J. The psychosocial effects of severe caries in 4-year-old children in Recife, Pernambuco, Brazil. Cad Saude Publica. 2005 Oct;21(5):1550-6.

38. Versloot J, Veerkamp JSJ, Hoogstraten J. Dental Discomfort Questionnaire: assessment of dental discomfort and/or pain in very young children. Community Dent Oral Epidemiol. 2006 Feb 1;34(1):47-52.

39. Clarke M, Locker D, Berall G, ... PP-P, 2006 undefined. Malnourishment in a population of young children with severe early childhood caries. Pediatr Dent. 2006;28(3):254-9.

40. Goettems ML, Ardenghi TM, Romano AR, Demarco FF, Torriani DD. Influence of maternal dental anxiety on oral health-related quality of life of preschool children. Qual Life Res. 2011 Aug 24;20(6):951-9.

41. Mafla AC, Villalobos-Galvis FH, Heft MW. Illness perceptions amongst individuals with dental caries. Community Dent Health. $2018 \mathrm{Mar}$ $1 ; 35(1): 16-22$.

42. Sischo L, Broder HL. Oral Health-related Quality of Life. J Dent Res. 2011 Nov 21;90(11):1264-70.

43. Piovesan C, Mendes FM, Ferreira F V., Guedes RS, Ardenghi TM. Socioeconomic inequalities in the distribution of dental caries in Brazilian preschool children. J Public Health Dent. 2010 Sep 1;70(4):319-26.

44. Sheiham A, Watt RG. The Common Risk Factor Approach: a rational basis for promoting oral health. Community Dent Oral Epidemiol. 2000 Dec 1;28(6):399-406.

45. Feldens CA, Giugliani ERJ, Duncan BB, Drachler M de L, Vítolo MR. Long-term effectiveness of a nutritional program in reducing early childhood caries: a randomized trial. Community Dent Oral Epidemiol. 2010 Apr 7;38(4):324-32.

46. Locker D. Disparities in oral health-related quality of life in a population of Canadian children. Community Dent Oral Epidemiol. 2007 Oct 1;35(5):348-56.

47. Ungar M. Resilience across Cultures. Br J Soc Work. 2006 Nov 8;38(2):218-35.

48. Schwarz JC, Barton-Henry ML, Pruzinsky T. Assessing Child-Rearing Behaviors: A Comparison of Ratings Made by Mother, Father, Child, and Sibling on the CRPBI. Child Dev. 1985 Apr;56(2):462.

49. McCarney R, Warner J, Iliffe S, van Haselen R, Griffın M, Fisher P. The Hawthorne Effect: a randomised, controlled trial. BMC Med Res Methodol. 2007 Dec 3;7(1):30.

\section{Figures}




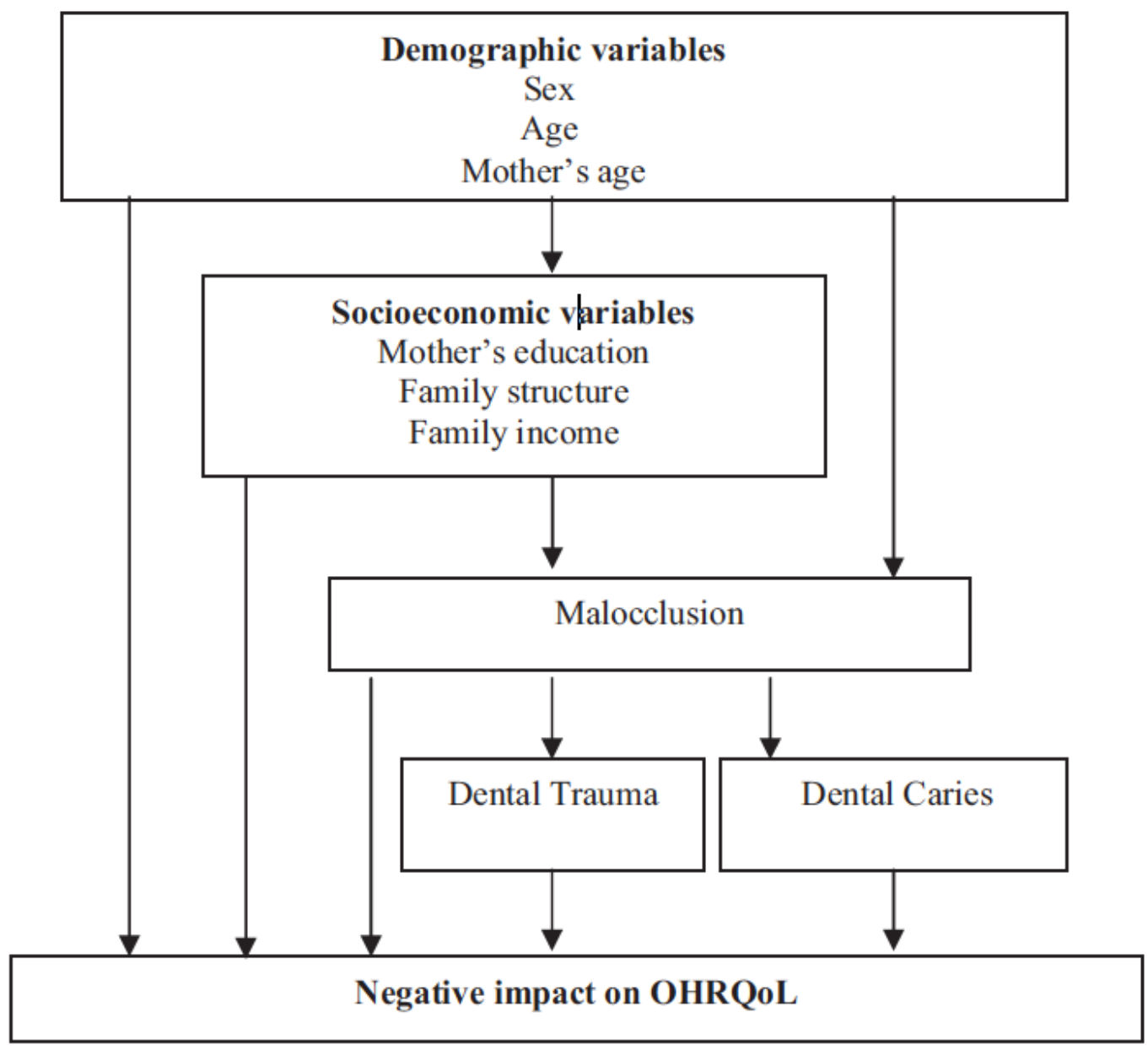

Figure 1

Conceptual hierarchical framework for Oral Health-Related Quality of Life. 